НАУКОВИЙ ВІСНИК

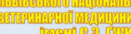

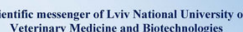

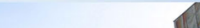

$\sqrt{1}$

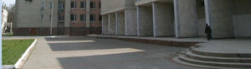

СЕРЯ: ВЕТЕРИНАРНН НАУКИ

Том 23 № 101

2021
Науковий вісник Дьвівського національного університету ветеринарної медицини та біотехнологій імені С.3. Гжицького. Серія: Ветеринарні науки

\author{
Scientific Messenger of Lviv National University \\ of Veterinary Medicine and Biotechnologies. \\ Series: Veterinary sciences
}

UDC 636.09:614.31:637.12

\title{
Research of factors affecting high sanitary and hyianic quality milk production (risk assessment for milk production)
}

\author{
M. O. Karavansky, V. O. Rud, L. O. Tarasenko \\ Odessa State Agrarian University Odessa, Ukraine
}

Article info

Received 15.01.2021

Received in revised form 17.02 .2021

Accepted 18.02.2021

Odessa State Agrarian University Panteleymonyvska Str., 13, Odessa, 65012, Ukraine

Tel.: +38-067-731-56-81

E-mail: tarasenko-

la1965@gmail.com

\begin{abstract}
Karavansky, M. O., Rud, V. O., \& Tarasenko, L. O. (2021). Research of factors affecting high sanitary and hyianic quality milk production (risk assessment for milk production). Scientific Messenger of Lviv National University of Veterinary Medicine and Biotechnologies. Series: Veterinary sciences, 23(101), 82-85. doi: 10.32718/nvlvet10114
\end{abstract}

Dairy cattle breeding in Ukraine is set the task that require a radical restructuring of the industry, bringing it out of a difficult crisis situation in order to increase the production of valuable food for the population and raw materials for industry The dairy industry is a very important part of all agricultural production. The socio-economic development of the state as a whole depends on the current situation in milk production. Quality milk must meet the requirements not only for physicochemical parameters (acidity, density, mass fraction of dry matter, protein, fat), but above all be safe, ie meet the current requirements for levels of contamination with microorganisms, the number of somatic cells, maximum permissible levels toxic elements, mycotoxins, residual amounts of antimicrobials, drugs and other substances. The quality and safety of cow's milk as a raw material is a global and unresolved issue for our country. The quality of milk cannot be improved in the process of its processing, so the milk quality management system at the enterprise should be focused on high-tech processes of its production, primary processing with the use of preventive measures. At present, the issue of high-quality milk production in Ukraine is urgent. Despite the trend, the population's demand for quality dairy products is increasing every year, so the issue of increasing the productivity of the dairy herd and milk quality through the use of modern high-tech conditions of keeping and milking. Therefore, the identification of factors influencing the process of milk production in farms is aimed at solving quality and safety problems and provides information on how to better and more effectively control hazards in the overall process.

Key words: safety, milking, milk, quality.

\section{Дослідження факторів, що впливають на виробництво молока високої санітарно-гігіснічної якості (оцінка ризиків за виробництва молока)}

\author{
М. О. Караванський, В. О. Рудь, Л. О. Тарасенко \\ Одеський державний аграрний університет, м. Одеса, Украӥна
}

\begin{abstract}
Перед молочним скотарством України поставлені завдання, що вимагають докорінної перебудови галузі, виведення ії зі складного кризового становища з метою збільшення виробництва цінних продуктів харчування для населення й сировини для промисловості. Молочна галузь є дуже важливою складовою ланкою усього сільськогосподарського виробництва. Від ситуації, що склалася у виробниитві молока, залежить соиіально-економічний розвиток держави в иілому. Якісне молоко має відповідати вимогам не тільки за фізико-хімічними показниками (кислотністю, густиною, масовою часткою сухих речовин, білка, жиру), а перш за все бути безпечним, тобто відповідати чинним вимогам щодо рівнів обсіменіння мікроорганізмами, кількості соматичних клітин, гранично допустимих рівнів токсичних елементів, мікотоксинів, залишкових кількостей протимікробних препаратів, лікарських засобів та інших речовин. Якість та безпечність молока коров'ячого як сировини є глобальною і невиріменою проблемою для нашої країни. Якість молока не можна підвищити в процесі його переробки, тому система управління якістю молока на підприємстві повинна бути орієнтована на високотехнологічні процеси його виробництва, первинну обробку з використанням профілакти-
\end{abstract}


чних заходів. Нині в Україні гостро назріло питання виробництва високоякісного молока. Незважаючи на виявлену тендениію, потреба населення в якісних молочних продуктах з кожним роком підвищується, тому актуальним залишається питання підвищення продуктивності дійного стада та сортності молока за рахунок використання сучасних високотехнологічних умов утримання та доӥння. Тому визначення факторів впливу на процес виробництва молока в господарствах спрямоване на вирішення проблем якості та безпеки і надає інформацію про те, як краще та ефективніше контролювати небезпечні чинники у загальному nроиесі.

Ключові слова: безпечність, доӥння, молоко, якість.

Вступ

Сьогодні в Україні існує кілька проблем щодо якості початкової сировини - молока, що знаходить своє безпосереднє відображення у виробництві низки молочних продуктів, які не відповідають у багатьох випадках встановленим національним (європейським) стандартам. Останнє засвідчує необхідність підвищення якості молочної продукції як для внутрішнього, так і для зовнішнього споживання, а також для того, щоб вітчизняні виробники молочної продукції могли успішно конкурувати на відповідному європейському ринку.

Коров'яче молоко - традиційний продукт харчування людини, який має унікальний хімічний склад $\mathrm{i}$ бактерицидні властивості. Відомий російський академік І. П. Павлов назвав молоко дивовижною їжею, приготованою самою природою, оскільки воно має всі необхідні речовини для росту і розвитку людського організму (Belov, 2005).

Якісне молоко має відповідати вимогам не тільки за фізико-хімічними показниками (кислотністю, густиною, масовою часткою сухих речовин, білка, жиру), а перш за все бути безпечним, тобто відповідати чинним вимогам щодо рівнів обсіменіння мікроорганізмами, кількості соматичних клітин, гранично допустимих рівнів токсичних елементів, мікотоксинів, залишкових кількостей протимікробних препаратів, лікарських засобів та інших речовин (Bernyk, 2019).

Якість питного молока залежить від початкового вмісту мікроорганізмів в сирому молоці, режиму термічного оброблення, видів мікроорганізмів, які залишились після пастеризації та тих, що потрапили в молоко з обладнання, активності термостійких протеолітичних і ліполітичних ферментів, температури зберігання готового продукту (Romanchuk et al., 2017).

Якість молока $є$ найважливішим чинником подальшого виробництва високоякісної молочної продукції. Чим вищою $є$ якість молока і чим швидше буде здійснено його переробку, тим якіснішою буде товарна молочна продукція. Зрозуміло, що конкурентоспроможність виробленої молочної продукції залежить в першу чергу від якості сировини (Novgorodska \& Blashchuk, 2015).

Переробник молока звертає увагу ще й на ступінь придатності сировини для виготовлення різних продуктів, якість і кількість яких багато в чому залежить від рівня бактеріального обсіменіння і вмісту соматичних клітин в сирому молоці (Lipych \& Momcheva, 2010).

\section{Результати та їх обговорення}

Проведення детального аналізу технологічних процесів виробництва молока в господарствах і встановлення факторів, що впливають на санітарногігієнічні показники якості та безпечності молока питання стратегічного значення.

Технологію виробництва молока необхідної санітарно-гігієнічної якості ми розглядаємо як процес категоріального характеру, який поділяється на ряд складників нижчого рівня - технологічних процесів. Кожний технологічний процес у свою чергу поділяється на технологічні операції, операції складаються 3 технологічних переходів, переходи в свою чергу поділяються на технологічні дії. Такий поділ технологічного процесу дає можливість скласти детальний план виконання кожної складової частини, в результаті технологічний процес буде виконано на високому виробничому рівні (Belov, 2005).

Процес виробництва молока на фермі включає в себе основні етапи, такі як:

- годівля (з моменту заготівлі кормів до збалансування раціонів відповідно до фізіологічних потреб організму), порушення будь-яких технологічних операцій на цьому етапі може призвести до метаболічних хвороб, що своєю чергою призведе до змін фізикохімічного складу молока та появи його вад;

- догляд та утримання тварин, що включає в себе належний санітарно-гігієнічний стан, забезпечуючи чистоту вимені у дійних корів, що своєю чергою відображається на кількості соматичних клітин в молоці та хворих на мастит корів.

- технологія доїння, що складається $з$ таких процесів: підготовка приміщення до доїння; санітарна обробка доїльно-молочного обладнання; підготовка операторів до доїння; підготовка вимені корів до процесу видоювання; під'єднання доїльних стаканів; процес видоювання; зняття доїльних стаканів; обробка дійок після доїння; охолодження молока та його транспортування на молокопереробні підприємства; миття та дезінфекція доїльного обладнання; приведення до належного санітарного стану приміщення для наступного доїння. Порушення гігієнічним вимог на даному етапі призводить до забруднення молока, обсіменіння його патогенною мікрофлорою, що призводить до невідповідності молока критеріям, регламентованим чинними нормативними документами.

Попадання в молоко інгібіторів (антибіотики, інші лікарські та миючі засоби) може бути пояснено різними причинами. До їх числа відносяться недотримання приписів щодо концентрації миючих і дезінфікуючих засобів, порушення режиму промивки, наявність залишків миючих засобів в обладнанні. Антибі- 
отики перешкоджають переробці молока, тому молочні заводи ретельно контролюють їх наявність у молоці (Zazharska, 2016).

Факторами, що визначають якість молока, $є$ його охолодження і зберігання на підприємстві-виробнику. Швидке охолодження попереджує розмноження мікроорганізмів, подовжує його бактерицидну фазу.

Отже, будь-яка невідповідність молока критеріям вимагає негайного застосування коригувальних заходів на рівні господарства. Усі перераховані етапи мають бути узгоджені як система профілактичних заходів, що спрямовані на виробництво молока високої санітарно-гігієнічної якості. Ці фактори повинні бути визначені як критичні точки керування гігієною та санітарією на молочних фермах.

Сире молоко від молочних корів може бути заражене мікроорганізмами, що надходять з вимені (мастит), зоонозними збудниками, що виділяються з заражених тварин, або іншими мікроорганізмами з навколишнього середовища. Мікроорганізми можуть переноситися в молоко через погану гігієну поверхонь вимені та сосків, від неочищеного та не дезінфікованого доїльного обладнання (Elmoslemany et al., 2009), а також від доярів та інших людей, які обробляють молоко. Порушення охолодження молока під час транспортування може також вплинути на кількість бактерій, збільшивши швидкість росту бактерій до того, як молоко потрапить до центрів збору молока або переробників. Загальна кількість бактерій використовується для оцінки того, наскільки такі процеси впливали на якість та безпеку молока.

Однак Мерфі С. К. та Бур К. Дж. (2000) зазначили, що загальне бактеріальне обсіменіння слід інтерпретувати 3 обережністю, оскільки різні типи бактерій можуть забруднювати молоко з різних джерел, таких як обладнання первинної обробки молока. Ці мікроорганізми розмножуються в молоці, оскільки молоко містить поживні речовини, має високу активність води та ідеальний рівень $\mathrm{pH}$ для їх росту та розвитку (Murphy \& Boor, 2000; Hassan \& Frank, 2011).

Тріланд І. та Фіксдел Л. довели, що у молоці можуть рости численні групи бактерій, але кишкова паличка особливо використовується як індикаторний організм для фекального забруднення харчових продуктів (тобто показник гігієни) і може бути пов'язана зі спалахами, що передаються через харчові продукти (Tryland \& Fiksdal, 1998).

Хіллертон Дж. і Беррі I. дослідженнями довели, що КСК (кількість соматичних клітин) в молоці може бути пов'язана 3 імунною реакцією організму. Субклінічний мастит у корів супроводжується зростанням кількості лейкоцитів в молоці без видимих візуальних змін зовнішнього вигляду молока, тимчасом як при клінічному маститі спостерігаються очевидні зміни в молоці, іноді в поєднанні з місцевими ознаками вимені або системними клінічними ознаками, які можна розпізнати (Hillerton \& Berry, 2005).

Високий рівень лейкоцитів, виміряний як КСК, i високий рівень загального бактеріального забруднення в молоці можуть призвести до вироблення ензимів, які погіршують компоненти молока, тим самим знижуючи його якість та якість молочних продуктів, отриманих в результаті переробки даного молока. Це вплине на термін придатності та зменшить прийнятність цієї продукції споживачами (Elmoslemany et al., 2009).

Судокс Р. Н. довів, що бактерії маститу, такі як Staphylococcus aureus та Streptococcus agalactiae, можуть забруднювати молоко та становити загрозу для громадського здоров'я, оскільки вони є патогенами зоонозних захворювань (Zadoks et al., 2011).

Камана О., Ружені Н. та Мбанзаміхіго Л. експериментально довели, що кілька інших збудників зоонозів, включаючи Brucella spp. та Salmonella spp., можуть бути виявлені у заражених тварин та забруднювати сире молоко, коли техніки доїння, гігієна та умови під час транспортування $є$ неоптимальними та некомфортними для тварин (Kamana et al., 2014; Rujeni \& Mbanzamihigo, 2014).

Підвищення якості та безпеки молока в усьому світі $є$ надзвичайно актуальним, оскільки норми, що захищають здоров'я споживачів, вимагають дотримання ключових вказівок щодо якості та безпеки молока, таких як низький рівень КСК. Максимально допустима концентрація КСК для змішаного молока, призначеного для переробки та споживання людиною, відрізняється залежно від регіону. Наприклад, Європейський Союз (2004 р.) вимагає обмеження КСК для молока $400 \times 10^{3}$ клітин/мл, США має обмеження 750 $\times 10^{3}$ клітин/мл, а Канада $-500 \times 10^{3}$ клітин/мл.

Східноафриканський стандарт для КСК становить $300 \times 10^{3}$ клітин/мл (EAS 67: 2006; Східноафриканське співтовариство, 2006), хоча це зазвичай не виконується. Хоч оплата за обсяг молока широко практикується, все частіше виникають заклики до диференційованої оплати молока відповідно до якості та безпеки його, оскільки переробники та споживачі приділяють більше уваги якості та безпечності молока і молочних продуктів (Hillerton \& Berry, 2005).

\section{Висновки}

Принципи НАССР є важливим інструментом, що використовується у харчовій промисловості для виявлення та контролю потенційних небезпек харчової безпеки 3 метою задоволення вимог споживача та вимог регуляторних органів.

Відомості про конфлікт інтересів. Автори стверджують про відсутність конфлікту інтересів щодо їх вкладу та результатів досліджень.

\section{References}

Addis, M. F., Tanca, A., Uzzau, S. Oikonomou, G., Bicalho, R. C., \& Moroni, P. (2016). The bovine milk microbiota: insights and perspectives from -omics studies. Molecular biosystems, 12(8), 2359-2372. URL: https://livrepository.liverpool.ac.uk/3001169/1/ c6mb00217j.pdf.

Baur, C., Krewinkel, M., Kranz, B., von Neubeck, M., Wenning, M., Scherer, S., Stoeckel, M., Hinrichs J., Stressler, T., \& Fischer, L. (2015). Quantification of 
the proteolytic and lipolytic activity of microorganisms isolated from raw milk. Int. Dairy J., 49, 23-29. doi: 10.1016/j.idairyj.2015.04.005.

Belov, Yu. P. (2005). Rozrobka ta vprovadzhennia systemy upravlinnia bezpechnistiu kharchovykh produktiv NASSR. Svit Yakosti Ukrainy, 2, 42-45 (in Ukrainian).

Bernyk, I. M. (2019). Innovatsiinyi pidkhid do oderzhannia vysokoiakisnoho moloka-syrovyny. Tekhnika, enerhetyka, transport APK, 3(106), 46-55 (in Ukrainian).

Du, B., Meng, L., Liu, H., Zheng, N., Zhang, Y., Guo, X., Zhao, S., Li, F., \& Wang, J. (2020). Impacts of Milking and Housing Environment on Milk Microbiota. Animals, 10, 2339. doi: 10.3390/ani10122339.

Elmoslemany, A. M., Keef, G., Dohoo I., \& Jayarao, B. (2009). Risk factors for bacteriological quality of bulk tank milk in Prince Edward Island dairy herds. Part 2: Bacteria count-specific risk factors. J. Dairy Sci., 92(6), 2644-2652. doi: 10.3168/jds.2008-1813.

Hassan A. N., \& Frank, J. F. (2011). Microorganisms associated with milk. Encyclopedia of Dairy Sciences (2nd ed.), Academic Press, San Diego, 447-457. doi: 10.1016/B978-0-12-374407-4.00309-5.

Hillerton, J. E., \& Berry, E. A. (2005). Treating mastitis in the cow-A tradition or an archaism. J. Appl. Microbiol., 98(6), 1250-1255. doi: 10.1111/j.13652672.2005.02649.x.

Ilchuk, M. M., \& Radko, V. I. (2013). Adaptatsiia vyrobnykiv moloka v Ukraini do yevropeiskykh vymoh. Bioresursy i pryrodokorystuvannia, 5/6, 129137 (in Ukrainian).

Kamana, O., Ceuppens, S., Jacxsens, L., Kimonyo, A., \& Uyttendaele, M. (2014). Microbiological quality and safety assessment of the Rwandan milk and dairy chain J. Food Prot., 77(2), 299-300. doi: 10.4315/0362-028X.JFP-13-230.

King, M. T. M., Matson, R. D., \& DeVries, T. J. (2021). Connecting farmer mental health with cow health and welfare on dairy farms using robotic milking systems. Animal welfare, 30(1), 25-38. doi: 10.7120/09627286.30.1.025.

Li, N., Richoux R., Boutinaud M., Martin P., Gagnaire V. (2014). Role of somatic cells on dairy processes and products: A review. Dairy Sci. Technol., 94(6), 517538. doi: 10.1007\%2Fs 13594-014-0176-3.

Lipych, L. H., \& Momcheva, A. M. (2010). Yakist molochnoi syrovyny V Ukraini: perspektyvy pidvyshchennia. Innovatsiina ekonomika, 16, 152-157 (in Ukrainian).

Malahovskij, V. F. (2005). Sistemy kachestva vazhnejshaja stupen' na puti v VTO. Molochnaja promyshlen-nost', 7, 13-15 (in Russian).

Murphy, S. C., \& Boor, K. J. (2000). Trouble-shooting sources and causes of high bacteria counts in raw milk. Dairy Food Environ. Sanit., 20(8), 606-611. URL: https://www.cabdirect.org/cabdirect/abstract/ 20000405566.

Novgorodska, N. V., \& Blashchuk, V. V. (2015). Milk quality problems in Ukraine. Scientific Messenger of LNU of Veterinary Medicine and Biotechnologies.
Series: Food Technologies, 17(1), 72-76. URL: https://nvlvet.com.ua/index.php/food/article/view/328 9.

Overkovska, T. K. (2018). Pravove rehuliuvannia bezpechnosti produktiv kharchuvannia. Pidpryiemnytstvo, hospo-darstvo i pravo, 4, 109-114 (in Ukrainian).

Postanova (IeS) № 178/2002 “Pro vstanovlennia zahalnykh pryntsypiv ta vymoh zakonodavstva shchodo kharchovykh produktiv, stvorennia Yevropeiskoho orhanu $\mathrm{z}$ bezpeky kharchovykh produktiv ta vstanovlennia vidpovidnykh protsedur $\mathrm{u}$ tsii haluzi" (in Ukrainian).

Postanova (IeS) № 853/2004 "Pro vstanovlennia spetsyfichnykh pravyl shchodo hihiieny kharchovykh produktiv tvarynnoho pokhodzhennia" (in Ukrainian).

Rastorguev, P. V., \& Pochtovaja, I. G. (2007). Obespechenie kachestva i bezopasnosti molochnogo syr'ja na osnove vnedrenija principov NASSR. Vesnik Nacional'noj Akademii Nauk Belorusii. Serija Agrarnye Nauki, 1, 27-29 (in Russian).

Romanchuk, I., Rudacova, T., \& Moiseeva, L. (2017). Influence of ultra-pasteurisation on characteristics of milk. Scientific Messenger of LNU of Veterinary Medicine and Biotechnologies. Series: Food Technologies, 19(80), 169-173. URL: https://nvlvet.com.ua/index.php/food/article/view/3071.

Rujeni, N., \& Mbanzamihigo, L. (2014). Prevalence of brucellosis among women presenting with abortion/stillbirth in Huye, Rwanda J. Trop. Med., 2014, Article ID 740479. doi: 10.1155/2014/740479.

Tryland, I., \& Fiksdal, L. (1998). Enzyme characteristics of beta-D-galactosidase-negative and beta-Dglucuronidase-positive bacteria and their interference in rapid methods for detection of waterborne coliforms and Escherichia coli. Appl. Environ. Microbiol., 64(3), 1018-1023. URL: https://www.ncbi.nlm.nih.gov/pmc/ articles/PMC106360.

Wallace, C., \& Williams, T. (2001). Pre-requisites: a help or hindrance to HACCP? Food control, 12(4), 235240. doi: 10.1016/S0956-7135(00)00042-6.

Wang, Y., Nan, X., Zhao, Y. et al. (2021). Rumen microbiome structure and metabolites activity in dairy cows with clinical and subclinical mastitis. J Animal Sci Biotechnol, 12, 36. doi: 10.1186/s40104-020-00543-1.

Zadoks, R. N., Middleton, J., McDougall, S., Katholm, J., \& Schukken, Y. (2011). Molecular epidemiology of mastitis pathogens of dairy cattle and comparative relevance to humans J. Mammary Gland Biol. Neoplasia, 16(4), 357-37. doi: 10.1007/s10911-011-9236-y.

Zazharska, N. M. (2016). Bakterialne zabrudnennia moloka za riznykh temperatur i terminiv zberihannia. Naukovyi visnyk Lvivskoho natsionalnoho universytetu veterynarnoi medytsyny ta biotekhnolohii imeni S. Gzhytskoho. Seriia: Veterynarni nauky, 18(3), 108-111. doi: 10.15421/nvlvet7025 (in Ukrainian).

ICO 22000 Systema menedzhmentu bezpechnosti kharchovykh produktiv. Vymohy do orhanizatsii lantsiuha vyrobnytstva ta postachannia. URL: https://uk.baker-group.net/articles/publikatsii/201509-29-20-08-53-813.html (in Ukrainian). 